\title{
ESSENTIAL NOTIONS CONCERNING THE INTEGRATION OF REFUGEES
}

\author{
BERTALAN DECMANN ${ }^{I}$
}

\begin{abstract}
The latest wave of refugees, which peaked in 2015, raises the question of what we mean by integration, not only in terms of the rules adopted in the EU, but also in terms of the social inclusion of individual refugees and their families. This is because the concepts in the literature, in EU documents on asylum, and in individual sectoral policies (e.g. social, employment, housing, health and public education) are not necessarily harmonized. Therefore, the aim of the study is not only to review integration outcomes, but also to distinguish concepts related to migration, asylum, and refugee discourse, such as exclusion, disintegration, acculturation, and assimilation. Only clarification will bring us closer to selecting the most important social policy and asylum measures. This clarification is also urgent because a coherent integration policy must comply with both cultural diversity and non-discrimination requirements in the EU.
\end{abstract}

KEYWORDS: refugee, integration, acculturation, exclusion, inclusion, assimilation, disintegration

\section{INTRODUCTION}

In the second half of the 2010s, a flood of asylum-seekers arrived in Europe ${ }^{2}$ - the biggest wave of displaced people since World War II (Stearns 2020) causing changes not only in the European Union's system, but also in the lives

1 Bertalan Decmann is PhD Student at the Doctoral School of Sociology, Faculty of Social Sciences, Eötvös Loránd University of Budapest; email: decmann.bertalan@tatk.elte.hu. This work was supported by the EFOP-3.6.3-VEKOP-16-2017-00007 project.

2 In the EU, the number of first-time asylum applicants was 1,322,850, in 2015, 1,260,920 in 2016 and 712,250 in 2017. Source: https://tinyurl.com/2r2j4wpx [Last accessed: 0920 2020] 
of Member States. The arrival and protection of asylum-seekers was not new and unknown for Member States - some of the latter were already destination countries of massive immigration over the last decades (such as France and Britain) - but in the middle of the last decade, they were unprepared for the high number of newcomers.

The terms used in EU policies by various governments and in scientific circles, including exclusion, disintegration, inclusion, integration, and assimilation, can be considered policy goals, outcomes, or outcomes of the integration process. Further, some can also serve as indicators of the effectiveness of programs or measures.

What are these terms used for, and when? In this paper, we will clarify the concepts of exclusion, disintegration, acculturation, assimilation, integration, and inclusion. These terms have an important place in the discourse about asylum-seekers and refugees, in their integration, and in research concerning them. The concepts have been selected because they are the most common policy goals/outcomes related to asylum-seekers and refugees. Acculturation is not considered a political strategy or individual outcome of integration, but rather a process of "changes in cultural mores resulting from direct and continuous contact and interaction between groups of different culture."3 Precise knowledge of the concept of acculturation is necessary, therefore the study will begin by describing this.

The main focus of the paper is multiple European countries, including Germany, France, Spain and the UK, ${ }^{4}$ which are the main destinations of massive immigration. From the point of view of immigrants and asylum-seekers, Hungary is not a target destination but a migration transit country. According to statistics from the Asylum Information Database, ${ }^{5}$ in 2019 there were 468 first-time asylum applicants in Hungary: of these, only 22 persons were granted refugee status, and 31 persons were granted subsidiary protection. However, the content of the paper is relevant to all countries which receive immigrants and asylum-seekers. The way a country treats immigrants and asylum-seekers contributes to how newcomers adapt to society. Inadequate immigration policy can lead to serious problems in the future - for example, see the failure of integration policy in France and Britain (Schain 2009).

3 https://tinyurl.com/35427ek3 [Last accessed: 0524 2020]

4 https://tinyurl.com/tt3trw3s [Last accessed: 0930 2020]

5 https://www.asylumineurope.org/reports/country/hungary/statistics [Last accessed: 0930 2020]

CORVINUS JOURNAL OF SOCIOLOGY AND SOCIAL POLICY VOL. 12 (2021) 1 


\section{ACCULTURATION}

A person's individual behavior is influenced by the culture (environment) which surrounds them. Acculturative change occurs when one's culture of origin and culture of residence differ. According to Akarowhe (2018), "acculturation is a process in which an individual adopts, acquires and adjusts to a new cultural environment." When a person starts to adopt the host society's culture, they undergo not only cultural but also social and psychological change. During acculturation, people can change their attitudes, beliefs, and behaviors. The process starts automatically after an individual arrives in a culture which differs from theirs. Another term for consideration, but one not to be used as a synonym of acculturation, is deculturation, which means abandoning old values and behaviors.

The concept of acculturation dates back to European colonization. At that time, according to Berry (2003), there was concern regarding the effects of European domination over indigenous peoples. The focus of acculturation later shifted to how immigrants changed following their entry and settlement into receiving societies. More recently, the main question associated with acculturation concerns how ethnocultural groups relate to each other as they try to live together in a multicultural society (Berry 2003:17). The acculturation process concerns how immigrants sustain ties to their culture of origin, and how they develop ties to their new destination's culture. Previously, it was only conceivable as a one-way process, whereby newcomers gave up their own identities and cultures and fully adapted to host societies (Gordon 1964) - i.e., a process according to which minority groups adopt the host society's cultural patterns. In the course of acculturation, the level of prejudice and discrimination decreases. We can also define acculturation as the result of continuous, direct contact between two or more different cultural groups and/or individual members (Fox et al. 2013).

At the micro level, acculturation means the psychological change that results from cross-cultural contact and the alteration of daily behavior patterns (Berry 2003). The condition for change is long-term exposure to a cultural environment that is different from the one in which an individual was socialized (WardGeeraert 2016).

Acculturation, according to Berry, is the effect and consequence of a prolonged encounter with another group, along with the changes and behaviors that occur as a result of this (Berry 1997). Acculturation as cultural adaptation has multiple components, some of which are easier to adapt, such as eating habits. Some of them, on the other hand, are more complex, like the formed attitudes, norms, and values of the host society. An important indicator of acculturation is that subcultures generally survive. As reported by Berry (1997), the process of 
acculturation has four possible outcomes: integration, separation, assimilation, or marginalization. ${ }^{6}$ The outcome depends on the degree of identification with the culture of origin and the host culture.

The European Commission's definition of acculturation is as follows: "A series of changes in cultural mores (ideas, words, values, norms, behavior, institutions) resulting from direct and continuous contact and interaction between groups of different cultures, particularly through migratory movements or economic exchange, the media and other channels." 7

In conclusion, acculturation is a process whereby a person lives in a foreign culture for a longer period of time and accepts and takes on the value system and the way of thinking of that culture over time through a process of cultural and psychological change (Bogáromi-Malota 2017). The notion is not used as a measure of integration, or as a political strategy, but instead refers to a process, the outcome of which depends mainly on the social policy of the host society and the will of the immigrant, refugee, individual, or group. These interactions are present from the beginning of the migration, and the longer the migration lasts, the stronger the effect.

\section{WHAT IS EXCLUSION?}

The notion of social exclusion was originally used by the French socialist governments of the 1980s. In social policy, the term refers to a disparate group of people living on the margin of society without access to the system of social insurance (Percy-Smith 2000). Exclusion - from participation in communities, cultural, political, social, and economic life - is one of the greatest problems facing individuals in society today. Social exclusion is the opposite of inclusion. It is based on group membership, such as ethnicity. Max Weber refers to social closure as one of the collective manifestations of the competition of social groups; i.e., when one group excludes another, based on its external attributes, from (economic) competition. External features can be ethnicity, religion, language, or social background (Brown-Crompton 2000).

Exclusion could mean protecting a group by removing individuals/groups (who are immoral or disagreeable individuals - in other words, unwanted members)

\footnotetext{
6 Assimilation: when the culture of the host country replaces one's own. Separation: when refugees retain their own culture and reject the host society's. Marginalization: when one belongs to neither the culture of the host country nor the culture of one's origin.
}

7 https://tinyurl.com/35427ek3 [Last accessed: 0524 2020]

CORVINUS JOURNAL OF SOCIOLOGY AND SOCIAL POLICY VOL. 12 (2021) 1 
that are threatening others (Doolaard et al. 2020). In this way, exclusion could be a beneficial for a group. However, immigrants, ethnic groups, and asylumseekers do not necessarily represent a threat to a population, yet they are often the target of exclusionary policies. In practice, governments exclude individuals or groups that are - in their opinion - threatening others.

Exclusion may be distressing for the actors who exclude others (Doolaard et al. 2020). Research shows that "people suffer psychological costs when they comply with directives to cause others social pain because doing so thwarts basic psychological needs" for autonomy and relatedness (Legate et al. 2013).

Social exclusion can have effects on a person's health and well-being. Victims of social exclusion can perceive themselves as less human than others. It "reduces the extent to which people believe that they possess attributes that are fundamental to our shared humanity (i.e., human nature)" (Bastian-Haslam 2010). It is common for people to blame victims and have negative attitudes toward the targets of social exclusion, like minorities (Beißert et al. 2020).

Social exclusion also involves different levels of deprivation. One of the most obvious factors of exclusion is poverty, but the term also refers to inadequate education, health, housing rights, and access to services (Percy-Smith 2000). It affects individuals and groups that are in some way subject to discrimination or segregation.

The exclusion of immigrants and asylum-seekers by governments involves a narrower meaning of social exclusion, whereby the target of exclusion is a specific group. According to Castles (1995), there are different levels of exclusion which governments can apply to individuals or groups. The strongest level of exclusion is total exclusion, in which governments try to prevent the entry of immigrants into a country. However, the power of global migration and a country's economic power may be more decisive factors than governmental decisions, so it is very difficult to maintain total exclusion. Another type of exclusion, according to Castles, is differential exclusion. In this case, immigrants are allowed to participate in specific areas of society (like the labor market), but their access to other segments (citizenship, the welfare system, or political participation) is denied. This can easily be made effective through legal mechanisms (rejection of naturalization, or sharp distinctions between the rights of citizens and noncitizens) or with informal practices (racism or discrimination). If a government acts this way, refugees can become ethnic minorities that are part of society, but excluded from full participation in cultural, social, and economic relations. The motivation for differential exclusion is that the reception of migrants and refugees is just a temporary solution.

According to de Haan and Maxwell (1998), there are three areas of social exclusion: rights, resources, and relationships. A lack of rights is visible in 
the fact that - for example - the excluded are not eligible for federally funded support, family reunion, employment, or a basic income. Second, in the field of resources, many refugees arrive in the host country poorly educated, without any skills and without knowing the official language. Another key factor of exclusion is relationships - the negative impact of experiences of racism and victimization.

Poverty is one of the key aspects of social exclusion, but there are other dimensions which are also relevant, especially considering the situation of refugees. Asylum seekers may be excluded nowadays because of the suspected correlation between them and economic factors or criminality (such as unemployment and terrorism). Asylum seekers are usually detained after arriving in a country, thus they experience physical exclusion first. Sometimes they are held in detention centers, transit zones, or in refugee camps for years. These places are remote areas enclosed with fences, just as asylum-seekers are physically and symbolically separated from national territories. Those who are in detention receive basic security, get access to health care, training, etc., but some of their basic rights are suspended (such as the right to free movement, to gather, or to work). They are thus excluded from these rights and freedoms (Neto 2018).

Although this paper is not specifically about Hungary, but more about the countries of mass immigration, Hungary's former transit zones can be considered an example of exclusionary practice. Transit zones were built at the country's southern border with Serbia. Asylum seekers were held there until the end of their asylum procedure, which in some cases lasted more than 28 days. The European Court of Justice (ECJ) classified these zones as detention zones, in which no one should be detained for longer than 28 days. ${ }^{8}$

Asylum seekers and refugees are often excluded from resources, rights, services, and activities, as well as relationships with people in society. Social exclusion includes legal sanctions involving systematic discrimination. This can also indicate the malfunctioning of society because the latter cannot provide for the needs of particular groups (Correa-Velez et al. 2013). In a new cultural environment, refugees face socio-economic disadvantages, a lack of social support, and experience discrimination. They have often had traumatic experiences in their home countries or during transit to the new host country. Factors like their lack of citizenship and knowledge of the country's official language and experiences of racism and discrimination can "contribute to anxiety, depression and feelings of social isolation" (Correa-Velez et al. 2013). These definitions from the literature can be clearly examined if people who have

8 https://tinyurl.com/pda95txs [Last accessed: 1006 2020]

CORVINUS JOURNAL OF SOCIOLOGY AND SOCIAL POLICY VOL. 12 (2021) 1 
received international protection in a country are granted the same or quasiidentical rights as citizens (for example, in Hungary) because they do not have the proper conditions to exercise them (if, for example, they do not speak the country's official language; lack social capital and culture-specific knowledge; have difficulty of accessing to public services), so they will actually be excluded. In other words, legal regulations alone cannot be a tool for calibrating the effectiveness of measures.

\section{DISINTEGRATION}

The EU's integration acquis has been severely weakened by economic, political, and external relations crises of recent years. However, we are not referring here to the institutional weaknesses of the EU and (nationalist, sovereign) aspirations that undermine integration (e.g. EuroMemorandum 2017), but about social disintegration in the context of migration processes. Disintegration is opposite of the process of integration, as "the process of coming to pieces" or, in other words, "the process of losing cohesion or strength" (Oxford English Dictionary 2020).

The notion is not strongly related to immigrants or refugees; nevertheless, it is often observed in discourses about migration and its consequences, especially since 2015. Many articles, debates and pieces of research that consider disintegration are about the European Union's disintegration. Articles (like that of Tassinari 2016) discuss how the process of the renationalization of European policymaking begun with the migrant and refugee crisis, especially in the field of security policy. Tassinari argued that earlier integration represented the European response to every major shift in Europe, and nations endeavored to create stability by opening their borders to each other. This integration ended with border closing and barrier erecting. National-level responses involve a variety of emergency measures, like border controls and border fences, that are aimed at restricting the number of border crossings. According to Tassinari, the new direction for the EU points towards to the renationalization of European politics as the best way forward.

Another author, Münchau, claims in an article that Member States have lost their will to solve problems collectively that should be solved at the EU level, not at the national level. This means the beginning of the age of disintegration, after 60 years of integration, and this change will make the EU less effective (Münchau 2016). Individual solutions by Member States have created fragmented, uncoordinated governance. This has challenged one of 
the EU's core values: solidarity (Morsut-Kruke 2018). If the EU cannot deal with refugees, the existential raison d'etre of European integration will fail. The continent's problems can be best solved only by cooperation, as the authors suggest.

In Germany, the word disintegration has been used in debate to refer to the exclusion of certain individuals from society, as well as to the supposed coming apart of society. However, disintegration is not equal to exclusion - it refers to the process of the falling apart of something whole. Disintegration policies can cause the exclusion of certain individuals. Disintegration policies sometimes set out to do harm and discourage the settlement of immigrants. An example is Theresa May's call in October 2013 for a "really hostile environment for illegal immigrants" in the UK. This included actions such as denying asylum-seekers' right to work (Collyer et al. 2020). There are government policies that aim to exclude groups from the beneficial impact of integration policies, and policies which are intended to undermine the integration of a group. Undermining the integration process is the beginning of disintegration (Collyer et al. 2020).

Disintegration policies aimed at refugee or immigrant groups often cause the latter's marginalization, thus their chance for school success or employment is significantly less than that of other citizens.

\section{ASSIMILATION}

Assimilation is when adaptation into society is a one-sided process. Assimilation can be a process, as well as the purpose of a policy. It is a political aim which can be only achieved by immigrants or refugees fully embracing the culture, dominant values, and norms of the host country, which will ultimately lead to the "weakening of discrimination based on ethnic origin" (Alba-Nee 2003). The point of assimilation is merging due to the loss of one's own culture. During the process of assimilation, immigrants and refugees must give up their distinctive linguistic, cultural, and social characteristics. During assimilation, individuals or groups lose their own culture through fusion with the host society (Varga 2006; Castles 1995). For individual adaptation, the state must create favorable conditions for immigrants and refugees. For example, by helping them to learn the dominant language and accepting their kids into normal schools among children of native-born individuals.

As an International Organization for Migration (IOM 2019) definition states, the purpose of assimilation is "to become less socially distinguishable from other members of the receiving society." Essentially, it is a straightforward 
and irreversible process (Ladányi 2011). Assimilation was earlier not seen as a process which in all cases ended with the erasure of all signs of ethnic origin. Park and Burgess (1921) by the concept of assimilation meant a social process - a union in which individuals and groups acquire the attitudes and feelings of the host nation and become one with them in shared cultural life. Park (1928) argued that if immigrants meet other people and societies in a country or culture which differs from that of their origin, it will always result in assimilation. In his opinion, during this relationship, competition and conflict develops, which will eventually result in the adaptation of the minority group. However, this process takes a lot of time, sometimes decades. Gordon (1964) argued for a process of assimilation that takes generations, in which cultural assimilation transforms into structural assimilation. According to Gordon, the assimilation process has different stages. Gans holds similar views (1997), according to which immigrants' and refugees' generations are the core of ethnic change. Every new generation represents a new stage of adaptation to the host society. Cultural and psychological processes take place over a long period of time, sometimes years or even decades. The process of assimilation continues as long as culturally different groups are in contact. The European Commission's definition also notes that the process is time-consuming: "[...] gradual process by which a minority group's second and third generations adopt the patterns of behavior of a majority group or host society and are eventually absorbed by the majority group / host society."9

Assimilation policies were popular for a long time until former receiving countries like Britain, Canada, and Australia replaced their assimilation policies with integration policies in most cases. In the 1960s, these countries recognized that immigrants were not assimilating like before - they were rather forming social and political associations and maintaining their culture and language (Castles 1995). Over time, the content of assimilation also changed: it was not the same as in the beginning or in the middle of the twentieth century. Nations, especially the USA, became more complex due to the many ethnic influences that became part of their mainstream repertoire (Alba-Nee 1997).

Different immigrant groups assimilate into different segments of society, which is another factor, and one which could result in either downward or upward assimilation for ethnic groups depending on the culture to which they assimilate. Segmented assimilation theory - as the name suggests - meant the end of straight-line theory, the claim of which was that the mobility of descendants of immigrants would be upwards. According to Gans (1992), changes happened

\footnotetext{
$9 \mathrm{https}$ //ec.europa.eu/home-affairs/what-we-do/networks/european_migration_network/glossary_ search/assimilation_en [Last accessed: 0524 2020]
} 
after reforms in 1965 in the USA..$^{10}$ The integration of immigrants and refugees became more difficult and reduced the chances of the second generation being as successful in terms of social mobilization as before. "Many of the post-1965 immigrants are coming into a different economy, in which selective migration may count for nothing after the first generation, and traditional opportunities for the upward mobility of later generations could be absent for some or many."

Denmark's refugee policy is labeled assimilation policy. In 2018, the Danish Parliament agreed on the new 'ghetto plan' to regulate life in 25 low-income and heavily Muslim enclaves. The plan includes: "Obligatory daycare for children from the age of one. If parents fail to enroll their children, they will lose access to childcare support. Daycare continues to be voluntary elsewhere in the country. Language tests for non-Western children in kindergarten (not required outside of these areas)." "11 According to the UNHCR, the plan is hugely troubling. "The coercive assimilation measures run risk of fueling racial prejudice, xenophobia and intolerance" (Barry-Solensen 2018).

Nowadays, assimilation is not a desirable policy approach ${ }^{12}$ for integrating immigrants and refugees into host countries, mostly because of assimilation policies' one-sidedness and lack of focus on social cohesion, trans-nationalism, diversity, and tolerance. Immigrants' and refugees' cultural norms and values add more diversity and enrich society. Furthermore, respect for human rights (i.e. the cultural, religious and educational rights of people enjoying international protection) are difficult to reconcile with assimilation policies, although there have been efforts to do this in Europe.

\section{DESIRED INTEGRATION}

The New Pact on Migration and Asylum (EU Commission 2020) itself uses the terms quoted so far: these include term 're/integration' in 28 cases, the term 'inclusion' in 13 cases, and the term 'cohesion' in four cases. However, no reference to either acculturation or assimilation can be found in this latest

10 The Immigration and Naturalization Act of 1965 abolished quotas based on nation of origin for the first time since 1921. "Immigrant were selected based on individual merit rather than race or national origin." New immigration policies such as reuniting families and giving priority to skilled laborers and professionals occurred as well. These reforms changed immigration demographics and increased immigrant numbers. https://www.history.com/news/immigration-act-1965-changes [Last accessed: 0329 2021]

11 https://tinyurl.com/hd7vnm5k [Last accessed: 0524 2020]

12 See, for instance, OHCHR (2010:8). 
document, which takes a comprehensive approach to migration and asylum, building on new instruments of solidarity to be implemented in the coming years. It is clear that one of the three most common concepts, re/integration, is also the most desirable in the migration context. The new pact supports effective integration policies (in plural), which include different types and levels of integration services for newcomers, those in need of protection, for vulnerable groups, and equally the reintegration of returnees from the EU (preferably voluntarily or otherwise), as well as integration into local communities.

Integration, according to the most commonly used definition, means the insertion of separate parts into a larger whole. The word integer comes from the Latin which means 'whole.' There is no generally accepted definition, but the IOM's definition (2019) contains the essence of other definitions: "The two-way process of mutual adaptation between migrants and the societies in which they live, whereby migrants are incorporated into the social, economic, cultural and political life of the receiving community. It entails a set of joint responsibilities for migrants and communities and incorporates other related notions such as social inclusion and social cohesion."

Integration has been the goal of policies for the last 50 years or more, not just in liberal democracies. As Castles (1995) writes, the policies of integration are weaker forms of assimilation. The idea is that "adaptation is a gradual process in which group cohesion and interaction play an important part." Integration cannot be mandatory for minority groups; it can only be freely chosen. According to Berry and Kalin (1995), there are three preconditions for integration in societies: openness to the value of cultural diversity; a low level of prejudice; and positive attitudes among ethno-cultural groups. Integration is a two-way process: it requires the host society to be open and welcoming towards newcomer immigrants and refugees. In terms of integration, the host population's attitude is crucial.

Integration, in contrast to assimilation, leaves more room for the preservation of individuals' identities, values, and attitudes in the acculturation process. The cultural identity of minorities becomes of value to the host society and its preservation is an important part of successful integration (Bándy 2019). Integration also means the acceptance of multicultural policies, the recognition of immigrants' cultural identity, and tolerance of cultural diversity. In the integration process, it is assumed that immigrants and refugees who are also workers strive to integrate into the majority culture, and, in parallel, the host society treats the process with sufficient sensitivity, helping them to preserve their cultural identity (Barcy 2012).

Another difference between assimilation and integration is that the process of integration is faster. Second and third generations of immigrants' descendants 
do not have to integrate or adapt because they will be born and raised in the host society. They will face other types of difficulties, like structural barriers in education, or on the labor market (Collett-Petrovic 2014). In societies where the level of diversity is higher, these barriers are lower, but in homogenous populations, the descendants of immigrants will face these difficulties.

It is commonly accepted that integration is a two-way process, yet in theory, policy, and practice, the focus is more on refugees and immigrants themselves (Phillimore 2020). Policies tend to make the process one-way, and in practice immigrants play a major role, although society should also be actively involved in the process. In an integrating society, there is no difference between the native population and non-native population. These kinds of one-way integration models assume that a society is made up of domestic individuals and groups (non-immigrants) who are already integrated and who have better access to all types of capital (e.g. economic, political, social, cultural, and symbolic capital) (Klarenbeek 2019). A society like this has never existed. To integrate 'outsiders,' the internal - native - population must also change, thus as a result of the integration of immigrants, society must also change. As Klarenbeek writes, changes take place in the size and composition of society, and new institutional arrangements will be made to accommodate the political, social, and cultural needs of refugees.

Schinkel draws attention to another common misinterpretation of the notion of integration. He claims that the notion integrated or disintegrated cannot be applied to individuals (i.e. applied at the individual level), but only to the social whole, as 'integrated' is not an individual state. Despite this fact, the focus of integration policies is always the individual. Society as a whole is against individuals - or groups of individuals - "whose being signifies a certain degree of integration." As the author writes, research does not usually measure the level of integration of native citizens. Therefore, if the notion of integration is only applied to immigrants but not to society, society "gets purified." Thereby, if any problems occur - unemployment, or homophobia, for example - it will be shown that "these are not problems that exist and occur within society." The problems instead originate from outside of society, from individuals who are not integrated yet, thus problems must be solved at the level of groups, not at the national level (Schinkel 2018).

Integration can act as an index for measuring the level of immigrants' and refugees' adaptation to the host society. Researchers usually use quantitative techniques to assess the socioeconomic performance of migrants, and these results are usually compared to those for non-immigrants. Most research about integration is "measured by the present state or the final outcome in different domains" (Crul-Schneider 2010). The problem with this is that these appraisals 
are only snapshots of a long-term process. In measurement, the context in which immigrants and refugees live is an important factor. If they live in a segregated or ghetto area, where schools or the economy is weaker, these factors could negatively affect their integration.

In France, the Republican Integration Contract is the main tool for integration. This contract refers to a "two-day civic course and up to 200 hours of language training courses to reach an A1 level." There are various pilot programs, of which the aim is to promote integration in ways like providing support packages for accommodation, language and vocational training, or minimum income support. These programs are usually implemented through collaboration between state and non-state actors (Fine 2019).

The process of integration is thus important, especially because it affects individual well-being (El Khoury 2018), so the details of the integration policies that governments follow are crucial.

\section{INCLUSION}

Inclusion is "the process of improving the ability, opportunity, and dignity of people disadvantaged on the basis of their identity, to take part in society" (IOM 2019). This definition comes from the International Organization of Migration, but the concept of inclusion was not used earlier in the field of migration.

The notion was not just a response to social exclusion; it was more about making sure that all individuals are able to participate as valued, respected members of society. The idea of social inclusion originates from the $1970 \mathrm{~s}$ and 1980s. Social inclusion was Europe's response to the increasing number of people living in long-term poverty caused by the crisis in health and welfare programs (Omidvar-Richmond 2003).

Others (Varga 2015) say that the concept of inclusion was first used in the field of social policy for special education in relation to the successful institutional education of children and students with disabilities. Inclusion - the opposite of exclusion - may increase efficiency if it becomes determining in education and in society (Varga 2006). First, intervention in integrative kindergartens and schools was called inclusive. This meant that the environment was adapted in a supportive way to children and students with different needs (Varga 2015).

In the last decade, the scientific and political approach to this concept has changed in several ways around the world - for example, the range of people and groups who are the focus of action for inclusion has significantly expanded. This occurred after policy makers recognized that there are other individuals and 
groups who are endangered by exclusion processes. Today, some democratic principles are grounded on those legal documents which have identified a wide range of groups at risk of exclusion. Also, these documents set out how to pay special attention to preventing the latter's exclusion. At the European level, Article 14 of the European Convention on Human Rights $(1950)^{13}$ defines the basics of the prohibition of discrimination, ensures equal treatment, and defines the scope of directives and protected characteristics. In the EU, the Charter of Fundamental Rights (2000) ${ }^{14}$ also prohibits discrimination (Articles 20-21) but requires Member States to respect linguistic and cultural diversity (Article 23). Therefore, equality does not mean uniformity.

The reception of those who belong to other cultures and communities is a never-ending process - it involves constant work towards the idea that the constraints of exclusion in society should be eliminated. It means recognition and appreciation of all aspects of diversity (Kalocsainé-Varga 2005). The European Commission's definition is that social inclusion is a process that enables every citizen (including the most disadvantaged) to fully participate in society. ${ }^{15}$ Since the launch of the 'Lisbon Strategy' (2000), the EU has used the notion of social inclusion in legal and strategic documents.

Inclusion is more than just bringing outsiders in. According to Omidvar and Richmond (2003: IX), the following elements are the "cornerstones" of social inclusion:

- "Valued recognition: conferring recognition and respect on individuals and groups;

- Human development: nurturing the talents, skills, capacities and choices of children and adults to live a life they value and to make a contribution both they and others find worthwhile;

- Involvement and engagement: having the right and the necessary support to make/be involved in decisions affecting oneself, family and community, and to be engaged in community life;

- Proximity: sharing physical and social spaces to provide opportunities for interactions, if desired, and to reduce social distances between people;

- Material well-being: having the material resources to allow children and their parents to participate fully in community life."

It is believed by Varga (2015) that the policy of integration has been replaced by the policy of inclusion. In the integration process, the focus is on the individual

13 https://www.echr.coe.int/Documents/Convention_ENG.pdf [Last accessed: 0524 2020]

14 https://tinyurl.com/b9vhx5rr [Last accessed: 0524 2020]

15 https://ec.europa.eu/social/main.jsp?catId=1059\&langId=en [Last accessed: 0524 2020] 
who gets help from society to integrate. Systemic conditions remain unchanged, and change and adaptation are expected from individuals and groups. In contrast, the quintessence of inclusion is focusing on the environment itself. Reception will only be successful if the environment can adequately respond to the needs and requirements of those who exist in society. Hinz's (2002) opinion is that inclusion is an optimized and expanded interpretation of integration. Integration divides individuals into groups, while inclusion involves a large, heterogeneous group. In such a heterogeneous community, coexistence is the key to success. Inclusion is a quality means of practically implementing integration. In a heterogeneous community, interventions will only bring results if society itself becomes more inclusive. This approach argues that the starting point for social inclusion was integration, and the concept of inclusion has led to a new approach. In contrast to integration, inclusion suggests that there are no 'deficient' groups in society whose social integration should be focused on. Inclusion is rather about a heterogeneous group in which coexistence is important (Varga 2015).

Dutch integration strategy can be considered a form of inclusive policy. In the Netherlands, once an asylum-seeker is granted asylum, they are obliged to participate in an integration course. The course takes 600 hours, and refugees need to pass it within three years. The integration course focuses on learning the language and culture, and becoming prepared for the Dutch labor market. Because the participation of refugees in the labor market has been low, the government implanted several programs (tailored support and coaching in relation to finding work, etc.). Moreover, the government focused on providing subsidies to employers to motivate refugee employment (Knappert et al. 2019).

The UNESCO Convention on the Protection of Diversity of Cultural Expressions $(2005)^{16}$ defines common rules, principles, and points of reference for cultural diversity at the global level, and is intended to "promote respect for the diversity of cultural expressions and raise awareness of its value at the local, national and international levels." As written in UNESCO guidelines (2005) "inclusion has to be seen as a never-ending search to find better ways of responding to diversity"; i.e. as a process of identification and the removal of the barriers. An inclusive social environment is based on diversity, and for this reason it is important that both immigrants and refugees are equal members of society. Furthermore, their contribution to the economy "increase[s] their independence and boost[s] the economic health of local communities" (UNHCR 2019:3).

16 https://tinyurl.com/7ka3yf4s [Last accessed: 0524 2020] 


\section{SUMMARY}

Migration is as old as humanity. However, its form has changed over time, becoming a mass phenomenon, and now taking place in a global context (Csepeli-Örkény 2017). Thus, the immigration and reception of asylum-seekers is not a new phenomenon for European countries. Solidarity and integration are core values of the European Union, thus how Member States treat refugees and immigrants has an important social impact. In the course of promoting cultural diversity and multiculturalism - the coexistence of different groups in society - various expectations and strategies have been developed by the majority and minority. I have outlined different concepts which can refer to policy strategies, and at the same time can be the individual or social outcomes of the acculturation/integration process.

As the motto of the European Union says, "United in diversity." At first, this slogan came into use in 2000. "It signifies how Europeans have come together, in the form of the EU, to work for peace and prosperity, while at the same time being enriched by the continent's many different cultures, traditions and languages," as the Treaty of the European Union (Article 3) claims. Accordingly, ${ }^{18}$ the EU "shall combat social exclusion and discrimination, and shall promote social justice and protection, equality between women and men, solidarity between generations and protection of the rights of the child. It shall promote economic, social and territorial cohesion, and solidarity among Member States. It shall respect its rich cultural and linguistic diversity and shall ensure that Europe's cultural heritage is safeguarded and enhanced." This therefore requires the simultaneous fulfilment of two requirements together: treating diversity as a value, thereby avoiding (forced) assimilation and exclusion because of extremism, and the integration of people who enjoy international protection. The order of the notions presented in this paper is based on how the concepts are related to the inclusion of asylum-seekers and refugees based on the strength of their reception. This may be visualized using an imaginary axis that indicates the degree of the latter's inclusion into the host society. Integration, inclusion, and equal treatment lie on the axis between two extremes (assimilation and exclusion), and it is a shared task of Europeans to foster them effectively.

A nation's choice depends on the ruling government's attitude, which may be pro- or anti-immigrant, asylum-seeker, or refugee. At the same time, some of the notions may also be outcomes of the acculturation process. The concepts presented and described here impact the discourse about migration.

17 https://europa.eu/european-union/about-eu/symbols/motto_en [Last accessed: 0524 2020] 18 https://tinyurl.com/yc9rkjso [Last accessed: 0524 2020] 
The adaptation of refugees and immigrant to the host society is usually measured by their success in the most important areas of integration (employment, housing, relations, and language). However, researchers must be cautious with their findings, because the latter show only the current integration state of an area, and, as mentioned earlier, the process of integration takes time.

The future of societies and the European Union will depend on how they face the challenge of integrating refugees and immigrants, thus it is essential that their acts and decisions do not run counter to common European interests. Instead of promoting fear and hatred, governments should pursue policies that serve the interest of both the majority and minority. The New Pact (EU Commission 2020) targets lawful and managed migration and includes a wide range of coercive tools, strong law enforcement and control and surveillance measures, while providing money, a solidarity mechanism and professionaladministrative cooperation to assist with integration - not only for refugees, but also for Europeans.

\section{REFERENCES}

Akarowhe, K. (2018) Effects and remedies to cultural shock on the adolescent students. Sociology International Journal, Vol. 2, No. 4., pp. 306-309, DOI: $10.15406 / \mathrm{sij} .2018 .02 .00063$

Alba, R. - V. Nee (1997) Rethinking assimilation theory for a new era of immigration. International Migration Review, Vol. 31, No. 4., pp. 826-874, DOI:10.1177/019791839703100403

Alba, R. - V. Nee (2003) Remaking the American mainstream: Assimilation and Contemporary Immigration. Cambridge, Harvard University Press

Bándy, K. (2019) A magasan képzett bevándorló magyar munkavállalók akkulturációs stratégiáinak vizsgálata a munkavállalási brain drain problémakörében. In: Reisinger, A. - P. Kecskés - L. Buics - J. Berkes B. Balassa (eds.): "Kulturális gazdaság”. Kautz Gyula Emlékkonferencia elektronikus formában megjelenő kötete. Győr, Széchenyi István Egyetem, pp. 1-12, https://tinyurl.com/y94pglky [Last accessed: 0528 2020]

Barcy, M. (2012) Konfliktusok és elöitéletek - A vonzások és taszitások világa. Budapest, Eötvös Loránd Tudományegyetem, Társadalomtudományi Kar http://www.tankonyvtar.hu/hu/tartalom/tamop412A/20100011_konfliktusokeloiteletek /lecke22_lap2.html [Last accessed: 0522 2020]

Barry, E. - M. S. Sorensen (2018) In Denmark, harsh new laws for immigrant 'ghettos'. The New York Times, January 7, 2018; https://www.nytimes. 
com/2018/07/01/world/europe/denmark-immigrant-ghettos.html [Last accessed: 1006 2020]

Bastian, B. - N. Haslam (2010) Excluded from humanity: The dehumanizing effects of social ostracism. Journal of Experimental Social Psychology, Vol. 46, No. 1., pp. 107-113, DOI: 10.1016/j.jesp.2009.06.022

Beißert, H. - S. Gönültaş - K. L. Mulvey (2020) Social inclusion of refugee and native peers among adolescents: It is the language that matters! Journal of Research on Adolescence, Vol. 30, No. 1., pp. 219-233, DOI:10.1111/ jora.12518

Berry, J. W. (1997) Immigration, acculturation, and adaptation. Applied Psychology, Vol. 46, No. 1., pp. 5-34, DOI: 10.1080/026999497378467

Berry, J. W. (2003) Conceptual approaches to acculturation. In: Chun, K. M. - P. Balls Organista - G. Marín (eds.): Acculturation: Advances in Theory, Measurement, and Applied Research. Washington, American Psychological Association, pp. 17-37.

Berry, J. W. - R. Kalin (1995) Multicultural and ethnic attitudes in Canada: An overview of the 1991 National Survey. Canadian Journal of Behavioural Science / Revue canadienne des sciences du comportement, Vol. 27, No. 3., pp. 301-320, DOI: 10.1037/0008-400X.27.3.301

Bogáromi, E. - E. Malota (2017) Kultúrák közötti váltás - a fogyasztói akkulturáció irodalmának áttekintése. In: Dr. Bányai, E. - Dr. B. Lányi Dr. M. Töröcsik (eds.): Tükrözödés, társtudományok, trendek, fogyasztás. Pécs, Pécsi Tudományegyetem, Közgazdaságtudományi Kar, pp. 291299.

Brown, Ph. - R. Crompton (2000) Gazdasági átstrukturálódás és társadalmi kizárás. In: Lengyel, Gy. - B. Nagy (eds.): Az európai integráció társadalmi feltételei és hatásai. Budapest, Aula

Castles, S. (1995) How nation-states respond to immigration and ethnic diversity. Journal of Ethnic and Migration Studies, Vol. 21, No. 3., pp. 293-308, DOI: 10.1080/1369183X.1995.9976493

Collett, E. - M. Petrvic (2014) The Future of Immigrant Integration in Europe: Mainstreaming Approaches for Inclusion. Brussels, Migration Policy Institute Europe

Collyer, M. - S. Hinger - R. Schweitzer (2020) An Introduction. In: Hinger, S. - R. Schweitzer (eds.): Politics of (Dis)Integration. Cham, Springer, pp. 1-18, DOI: 10.1007/978-3-030-25089-8 1

Correa-Velez, I. - R. Spaaij - S. Upham (2013) 'We are not here to claim better services than any other': Social exclusion among men from refugee backgrounds in urban and regional Australia. Journal of Refugee Studies, Vol. 26, No. 2., pp. 163-186, DOI:10.1093/jrs/fes003 
Crul, M. - J. Schneider (2010) Comparative integration context theory: Participation and belonging in new diverse European cities. Ethnic and Racial Studies, Vol. 33, No. 7., pp. 1249-1268, DOI: 10.1080/01419871003624068 Csepeli, Gy. - A. Örkény (2017) Nemzet és migráció (Nation and Migration). Budapest, Eötvös Loránd Tudományegyetem, TáTK

De Haan, A. - S. Maxwell (1998) Editorial: Poverty and social exclusion in north and south. IDS Bulletin, Vol. 29, No. 1, pp. 1-9, DOI: https://doi. org/10.1111/j.1759-5436.1998.mp29001001.x

Doolaard, F. T. - G-J. Lelieveld - M. K. Noordewier - I. van Beest - E. van Dijk (2020) Get out or stay out: How the social exclusion process affects actors, but not targets. Journal of Experimental Social Psychology, Vol. 88, DOI: 10.1016/j.jesp.2019.103946

El Khoury, S. J. (2018) Factors that impact the sociocultural adjustment and wellbeing of Syrian refugees in Stuttgart - Germany. British Journal of Guidance and Counselling. Vol.47, No. 1.,pp. 1-16, DOI: 10.1080/03069885.2018.1520196

European Commission (2020) European Commission's Communication on A New Pact on Migration and Asylum (COM (2020)

Euromemorandum (2017) European Economists for an Alternative Economic Policy in Europe. The European Union: The Threat of Disintegration EuroMemorandum 2017, http://www2.euromemorandum.eu/uploads/euromemorandum_2017.pdf [Last accessed: 0810 2020]

European Migration Network's Glossary (2020) https://tinyurl.com/ya3tqoaq [Last accessed: 2205 2020]

Fine, S. (2019) The Integration of Refugees in France. In depth analysis requested by the EMPL committee, Policy Department for Economic, Scientific and Quality of Life Policies Directorate-General for Internal Policies, https://www.europarl.europa.eu/Reg Data/etudes/STUD/2019/638397/IPOL_ STU(2019)638397(ANN01)_EN.pdf [Last accessed: 0610 2020]

Fox, R. S. - E. L. Merz-M. T. Solórzano-S. C. Roesch (2013) Further examining Berry's model: The applicability of latent profile analysis to acculturation. Measurement and Evaluation in Counseling and Development, Vol. 46, No. 4., pp. 270-288, DOI: 10.1177/0748175613497036

Gans, H. J. (1992) Second-generation decline: Scenarios for the economic and ethnic futures of the post-1965 American immigrants. Ethnic and Racial Studies, Vol. 15, No. 2., pp. 173-192, DOI: 10.1080/01419870.1992.9993740

Gans, H. J. (1997) Toward a reconciliation of "assimilation" and "pluralism": The interplay of acculturation and ethnic retention. The International Migration Review, Vol. 31, No. 4., pp. 875-892, DOI: 10.2307/2547417

Gordon, M. M. (1964) Assimilation in American Life: The Role of Race, Religion, and National Origins. Oxford, Oxford University Press 
Hinz, A. (2002) Von der Integration zur Inklusion - terminologisches Spiel oder konzeptionelle Weiterentwicklung. Zeitschrift für Heilpädagogik, Vol. 53, No. 9., pp. 354-361.

IOM (2019) Glossary on Migration. Switzerland, International Organization for Migration, https://tinyurl.com/y94hzv6b [Last accessed: 2205 2020]

Kalocsainé Sánta, H. - A. Varga (2005) Az inklúzió mint társadalmi és oktatási idea. Educatio, Vol. 14, No. 1., pp. 204-208.

Kislev, E. (2019) Open markets, closed societies: the dual assimilation of immigrants in Western Europe. Social Science Research, Vol. 82, pp. 92-104, DOI: 10.1016/j.ssresearch.2019.04.004

Klarenbeek, L. M. (2019) Reconceptualising 'integration as a two-way process.' Migration Studies, pp. 1-20, DOI: 10.1093/migration/mnz033

Knappert, L. - H. van Dijk - V. Ross (2019) Refugees' inclusion at work: A qualitative cross-level analysis. Career Development International, Vol. 25, No. 1., pp. 32-48, https://doi.org/10.1108/CDI-01-2018-0021

Ladányi, J. (2011) Integráció, asszimiláció, szegregáció. In: Bárdi, N. - Á. Tóth (eds.): Asszimiláció, integráció, szegregáció. Párhuzamos értelmezések és modellek a kisebbségkutatásban. Budapest, MTA Kisebbségkutató Intézet, pp. 49-56.

Legate, N. - C. R. de Haan - N. Weinstein - R. M. Ryan (2013) Hurting you hurts me too: The psychological costs of complying with ostracism. Psychological Science, Vol. 24, No. 4., pp. 583-588, DOI: 10.1177/0956797612457951.

Morsut, C. - I. B. Kurke (2018) Crisis governance of the refugee and migrant influx into Europe in 2015: A tale of disintegration. Journal of European Integration, Vol 40, No. 2., pp. 145-159, DOI: 10.1080/07036337.2017.1404055 Münchau, W. (2016) Europe enters the age of disintegration. Financial Times, February 28, 2016, https://www.ft.com/content/f9c8bb52-dcac-11e5-854100fb33bdf038 [Last accessed: 0524 2020]

Neto, P. F. (2018) Ambiguous boundaries between exclusion and inclusion. Experiences from the Meheba Refugee Camp (Zambia). In: Aboim, S. P. Granjo - A. Ramos (eds.): Changing Societies: Legacies and Challenges. Lisbon, Instituto de Ciências Sociais, pp. 29-47, DOI: 10.31447/ ics9789726715030.01

OHCHR (2010) Minority Rights: International Standards and Guidance for Implementation. UN Office of the High Commissioner for Human Rights (OHCHR) HR/PUB/10/3, https://www.refworld.org/docid/4db80ca52.html

Omidvar, R. - T. Richmond (2003) Immigrant settlement and social inclusion in Canada. Toronto, Laidlaw Foundation

Oxford English Dictionary (2020) Disintegration, https://en.oxforddictionaries. com/definition/disintegration [Last accessed: 0929 2020] 
Park, R. E. - E. W. Burgess (1921) Introduction to the Science of Sociology. Chicago, University of Chicago Press, https://www.gutenberg.org/ files/28496/28496-h/28496-h.htm [Last accessed: 0929 2020]

Park, R. E. (1928) Human migration and the marginal man. American Journal of Sociology, Vol. 33, No. 6., pp. 881-893, DOI: 10.1086/214592

Percy-Smith, J. (2000) Policy Responses to Social Exclusion: Towards Inclusion? Philadelphia, Open University Press

Phillimore, J. (2020) Refugee-integration-opportunity structures: Shifting the focus from refugees to context. Journal of Refugee Studies, feaa012, DOI: $10.1093 /$ jrs/feaa012

Schain, M. A. (2009) The success and failure of integration policy in France and Britain: Convergence of policy and divergence of results. In: Prügl E. M. Thiel (eds): Diversity in the European Union. Palgrave Macmillan, New York, DOI:10.1057/9780230104167_3

Schinkel, W. (2018) Against 'immigrant integration': For an end to neocolonial knowledge production. Comparative Migration Studies, Vol. 6, No. 31., pp. 1-17, DOI: 10.1186/s40878-018-0095-1

Stearns, J. (2020) Europe's Refugees. Bloomberg, February 28, 2020, https:// www.bloomberg.com/quicktake/europe-refugees [Last accessed: 0930 2020]

Tassinari, F. (2016) The disintegration of European security: Lessons from the refugee crisis. PRISM, Vol. 6, No. 2., pp. 70-83.

UNESCO (2005) Guidelines for Inclusion: Ensuring Access to Education for All. Paris, United Nations Educational Scientific and Cultural Organization (UNESCO)

UNHCR (2019) MUN Refugee Challenge. Background Guide Economic Inclusion of Refugees, https://www.unhcr.org/5df9f0bc7.pdf [Last accessed: 0524 2020]

Varga, A. (2006) Multikulturalizmus - inkluzív oktatási rendszer. In: Forray, R. K. (ed.): Ismeretek a romológia alapképzési szakhoz. Pécs, Bölcsész Konzorcium, pp. 145-158.

Varga, A. (2015) Az inklúzió szemlélete és gyakorlata. Pécs, Pécsi Tudományegyetem Bölcsészettudományi Kar Neveléstudományi Intézet Romológia és Nevelésszociológia Tanszék, https://tinyurl.com/ybzr6az6 [Last accessed: 0524 2020]

Ward, C. - N. Geeraert (2015) Advancing acculturation theory and research: The acculturation process in its ecological context. Current Opinion in Psychology, Vol. 8, pp. 98-104, DOI: 10.1016/j.copsyc.2015.09.021 
